\title{
IAMJ
}

INTERNATIONAL

AYURVEDIC

MEDICAL JOURNAL

ISSN: 23205091

Impact Factor: 5.344

\section{TO STUDY THE EFFECT OF VAMANA KARMA AND NARDIYA LAXMIVILASA RASA IN THE MANAGEMENT OF DUSHTA PRATISHYAYA (ALLERGIC RHINITIS): A CASE STUDY}

\author{
$\underline{\text { Mishra Meenu }}{ }^{1}$, Shivhare Shwetal ${ }^{2}$, Sharma Vivek ${ }^{3}$ \\ ${ }^{1} 2^{\text {nd }}$ Year PG Scholar, ${ }^{2}$ Reader, ${ }^{3}$ Lecturer \\ Department of Kayachikitsa, Pt. Khushilal Sharma Govt. (Auto.) Ayurveda College and Institute, Bhopal, \\ Madhya Pradesh, India
}

Corresponding Author: mishrameenu654@gmail.com

\section{https://doi.org/10.46607/iamj5908102020}

(Published online: October 2020)

Open Access

(C) International Ayurvedic Medical Journal, India 2020

Article Received:26/09/2020 - Peer Reviewed:02/10/2020 - Accepted for Publication:04/10/2020

\section{Check for updates}

\section{ABSTRACT}

Background: According to Acharya Charaka nose is the gateway of head. Diseases related with upper respiratory passage affect the Prana Vata, Tarpaka Kapha, Sadhaka Pitta and Majja Dhatu. Allergic rhinitis is the most common disease of upper respiratory passage for visit to outpatient department. Prevalence of allergic rhinitis ranges from 20 to $30 \%$ in Indian population. It is an IgE-mediated immunologic response of nasal mucosa to airborne allergens and is characterized by watery nasal discharge, nasal obstruction, sneezing and itching in the nose. In Ayurveda allergic rhinitis has a high resemblance with Dushta Pratishyaya, which comes under Nasagataroga. It is described in Brihattrayee as well as Laghutrayee. Acharya Sushruta has given detailed description of DushtaPratishyaya. Aim \& Objectives: To study the effect of Vamana Karma and Nardiya Laxmivilasa Rasa in the management of Dushta Pratishyaya and to find out an effective Ayuvedic management for Dushta Pratishyaya (Allergic Rhinitis). Material and Methods: The present case study is upon a 40 years old (male patient) diagnosed case of Dushta Pratishyaya with complaints of recurrent episodes of sneezing, watery nasal discharge, coughing specially at night time, throat irritation and sometimes pain in trunk region since last 2 years, at the Kayachikitsa OPD of Pt. Khushilal Sharma Govt. Ayurvedic Hospital Bhopal. The patient was 
treated with Vamana Karma followed by Naradiya Laxmivilasa Rasa. Duration of study is 46 Days and follow up, every 15 days for 2 months. Assessment was done on the basis of symptomatic relief after treatment. Observation: Vamana Karma and Naradiya Laxmivilasa Rasa yielded symptomatic relief after treatment. The overall effect of the treatment in patient suggested that, there is $86.66 \%$ relief in patient. Conclusion: On the basis of result obtained, it can be concluded that Vamana Karma and Naradiya Laxmivilasa Rasa can be used as an effective treatment in the management of Dushta Pratishyaya (allergic rhinitis).

Keywords: Dushta Pratishyaya, Allergic rhinitis, Vamana Karma, Nardiya Laxmivilasa Rasa

\section{INTRODUCTION}

Brain receives the information outside the body surface through five sense organs viz. nose, tongue, ear, eye and skin. The olfactory mucous membrane is the place in the body where the nervous system is closest to the external environment. ${ }^{1}$ Nose is one of the important sense organs which is more prone to recurrent infection. Allergic rhinitis is one of the most common allergic diseases worldwide. Reported incidences of allergic rhinitis in India ranges between 20-30\%. ${ }^{2}$ Allergic Rhinitisis a disorder in which there are episodes of nasal congestion, watery nasal discharge and sneezing. It may be seasonal or perennial and is due to an immediate hypersensitivity reaction in the nasal mucosa. Seasonal antigens include pollens from grasses, flowers, weeds or trees. Perennial allergic rhinitis may be a specific reaction to antigens derived from house dust, fungal spores or animal dander, but similar symptoms can be caused by physical or chemical irritants, e.g. pungent odours or fumes, including strong perfumes, cold air and dry atmospheres. ${ }^{3}$ Allergic Rhinitis and Its Impact on Asthma (ARIA) has given the criteria for diagnosis of allergic rhinitis. ${ }^{4}$ In Ayurveda, allergic rhinitis through its sign and symptoms can be correlated with Dushta Pratishyaya which comes under Nasagata Roga. It is described in Brihattrayee as well as Laghutrayee. Acharya Charak (Ch.Chi.26 $6^{\text {th }}$ chp. Trimarmiya Adhyaya), Sushruta (Su.Ut.22 $2^{\text {nd }}$ chp. Nasagatroga Adhyaya \& $24^{\text {th }} \mathrm{c} \quad$ hp. Pratishyaya Pratishedhopkrama), Vagbhatta (A.H.Ut.19 $9^{\text {th }} \mathrm{chp}$.), Madhavakar (Ma.Ni.58 ${ }^{\text {th }}$ chp.), Bhava Mishra (Chikitsa Prakaran $65^{\text {th }}$ chp. Nasarogadhikara) and Sharangdhar (Sh.Sa.Pratham Khand Nasaroga Prakaran of Rogagananadhyaya) have described
Vataja, Pittaja, Kaphaja, Raktaja and Sannipataja Pratishyaya. Acharya Kashyap did not describe Raktaja Pratishyaya. Acharya Chakrapanidutta described Nava Pratishyaya and Jeerna Pratishyaya (58 ${ }^{\text {th }}$ chp.Nasaroga Chikitsa). Acharya Sushruta stated that if these five types of Pratishyaya are neglected in their initial stage then it leads to Dushta Pratishyaya which is Krichhasadhya (difficult to treat). ${ }^{\mathbf{5}}$ According to Acharya Vagbhatta symptoms of Dushta Pratishyaya are Sarvendriya Santapa, Agnimandya (indigestion), Jwara (fever), Kasa (coughing), Urahaparshwashool (pain in trunk region), Mukhadaurgandhya (halitosis), Nasa Kledata and Shushkata, Anahyata (obstruction) and Vivriyata (narrowing of nostrils) [A.H.Ut.19/9-13]. Acharaya Charak and Sushruta also accept loss of smell in Dusta Pratishyaya (Gandhat Na Veti). Modern management of allergic rhinitis includes an antihistamine, sodium cromoglycate and glucocorticoid nasal spray singly or in combination which is not satisfactory in long term therefore in this research paper a holistic approach to find out effective role of Vamana Karma ${ }^{6}$ and Nardiya Laxmivilasa Rasa $^{7}$ in the management of Dushta Pratishyaya. Effect of Vamana Karma and Nardiya Laxmivilasa Rasa will be observed with respect to its clinical effect on patient.

\section{Aim and Objectives}

- To study the effect of Vamana Karma and Nardiya Laxmivilasa Rasa in the management of Dushta Pratishyaya (Allergic Rhinitis).

- To find out an effective Ayuvedic management for Dushta Pratishyaya (Allergic Rhinitis). 


\section{Material and Methods}

- Selection and Source of patient: For this study, patient was registered from OPD of Kayachikitsa department and admitted in private IPD of Pt. Khushilal Govt. (Auto.) Ayurveda Hospital Bhopal.

- Plan of study: Patient taking allopathic medicine was stopped during the study period. The drugs required for Vamana Karma were procured and prepared in Prakalp of Panchkarma in Pt. KLS Govt. Ayurveda Hospital Bhopal.

- Duration of study- 46 Days Follow up-every 15 days for 2 months.

\section{Case Study}

A 40 years old male patient visited Govt. Ayurvedic hospital Bhopal (OPD no.-36389, IPD no.-670/116) with chief complaints of recurrent episodes of sneezing, watery nasal discharge, coughing specially at night time, throat irritation and sometimes pain in trunk region since last 2 years.

\section{History of Present Illness}

Patient was apparently normal 2 years back then suddenly sneezing and watery nasal discharge started and became worse. After having initial medication (under supervision of MBBS physician) he got temporary relief and symptoms were under control but later on he had got same episodes of sneezing, watery nasal discharge with night coughing. Patient was not getting much relief with allopathic medicines, so he came to Ayurvedic Hospital Bhopal on 27/02/2020 for Ayurvedic treatment. Patient is hypertensive since 4 years and also have urticaria since childhood.

\section{History of Past Illness}

- Medical history- on medication advised by MBBS physician.

- Surgical history- anal piles (operated 24 years back)
- Psychiatric history- no

Personal History

- Addiction- no, Occupation- shopkeeper, Appetitenormal, Sleep- disturbed (due to coughing), Bowel- clear, Micturition- normal, Allergy- have allergy for any kind of cold product.

\section{General Examination}

- Pallor, icterus, cyanosis, clubbing and oedema absent.

- Lymph node not palpable.

- $\mathrm{BP}-140 / 96 \mathrm{mmHg}$

- Pulse-70/min

- $\quad \mathrm{SpO}_{2}$ and all vitals were stable.

Systemic Examination

- CVS, P/A normal.

- RS- bilateral lungs sounds clear

- Nose- no DNS, no congestion

- Ears- both ear canals were clear, both tympanic membranes were intact

- Throat- congestion was seen

Investigation

- The lab investigation (05 ${ }^{\text {th }}$ March 2020) CBP- Hb $15 \%$, MCV 74.94\%, MCHC- 39.4g/dl \& rest normal, Lipid profile- triglycerides $237.6 \mathrm{mg} / \mathrm{dl}$, VLDL $47.52 \mathrm{mg} / \mathrm{dl}$ which were increased \&rest normal, LFT- total bilirubin $1.1 \mathrm{mg} / \mathrm{dl}$ which was increased\& rest normal, RBS- $98.9 \mathrm{mg} / \mathrm{dl}$, Blood Urea \& serum creatinine were normal and HIV was negative.

- On $5^{\text {th }}$ March 2020, USG (whole abdomen) was done which showed fatty liver grade I and rest normal. ECG was normal.

- On $7^{\text {th }}$ March 2020, Chest X-ray (PA view) was done, which showed right sided hilar gland enlarged and lung field clear. 


\section{Samprapti (Pathogenesis) [Ch.Chi26/104, Su.Ut.24/04]}

Nidana Sevana: Sandharan, Ajirna, Rajo, Atibhashya \& Rituvaishmya etc.<smiles>[CH]</smiles>

Sanchaya: Kaphadi Dosha Sanchaya in Sirah Pradesh
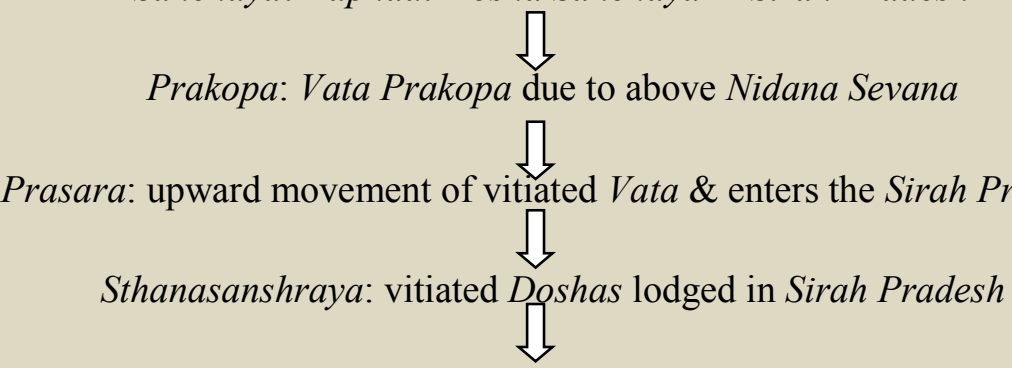

Pranavaha, Rasavaha \& Raktavaha Srotosanga

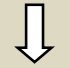

Vyaktavasta: Shirahshoola, Jwara, Kasa etc. symptom complex

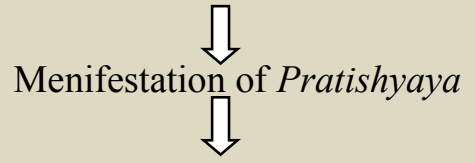

Neglected in intial stage (Kalantarjanaka)

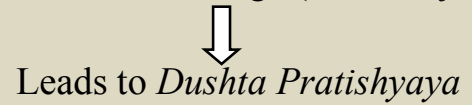

Table 1: Treatment Regimen

\begin{tabular}{|c|c|c|c|c|}
\hline Date & Treatment & Dose & Frequency & Duration \\
\hline $6 / 03 / 2020$ to & Deepan-Pachan with & & & 3 days \\
\hline \multirow[t]{2}{*}{$8 / 03 / 2020$} & Chitrakadi Vati & 2 tabs & q.i.d. & \\
\hline & Panchkol Phanta & $20 \mathrm{ml}$ & Every 2 hourly & \\
\hline $9 / 03 / 2020$ to & Snehapana with plain Goghrita, & $30 \mathrm{ml}$ to & Orally, empty & 7days \\
\hline \multirow[t]{3}{*}{$15 / 03 / 2020$} & start with $30 \mathrm{ml}$ in increasing dose & $250 \mathrm{ml}$ in & Stomach, once & \\
\hline & up to $250 \mathrm{ml}$ (till Samyak Snehana & increasing & in a morning & \\
\hline & Lakshana obtained) & Dose & & \\
\hline \multirow[t]{3}{*}{$16 / 03 / 2020$} & Sarvang Abhayang and Swedana & Q.S. & Once in a & 1day \\
\hline & with Narayan oil and Dashmool & & Morning & \\
\hline & Kwath & & & \\
\hline \multirow[t]{11}{*}{$17 / 03 / 2020$} & -Sarvang Abhayang and Swedana & Q.S. & & 1day \\
\hline & with Narayan oil and Dashmool & & & \\
\hline & Kwath, followed by & & & \\
\hline & -Vamana Karma with & & & \\
\hline & Madanfala Churna & $7 \mathrm{gm}$ & Once in morning & \\
\hline & Vacha Churna & $3.5 \mathrm{gm}$ & hours empty & \\
\hline & Saindhava Lavana & $1.25 \mathrm{gm}$ & stomach & \\
\hline & Madhu (honey) & Q.S. & & \\
\hline & Patient got 6 Vega & & & \\
\hline & (Madhyam Shuddhi) after that & & & \\
\hline & -Vairachanika Dhoompana done & & & \\
\hline $17 / 03 / 2020$ to & Samsansarjana Karma & - & - & 5 days \\
\hline
\end{tabular}




\begin{tabular}{|l|l|l|l|}
\hline $21 / 03 / 2020$ & (Diet control) & - & - \\
\hline $22 / 03 / 2020$ to & Na. Laxmivalasa Rasa & $250 \mathrm{mg}$ & b.d. with lukewarm water \\
\hline $20 / 04 / 2020$ & & & \\
\hline
\end{tabular}

\section{Assessment Criteria}

- Gradation Pattern-Assessment was done on the changes in the subjective parameters before and after treatment.
- Each sign and symptom is graded, and a numerical value is given for assessment of results. The change and relief in symptoms were observed on completion of treatment.

Table 2: Clinical Assessment

\begin{tabular}{|c|c|c|c|c|c|}
\hline S. No. & Subjective & Parameters & Scoring & BT & AT \\
\hline & Symptoms & & & & \\
\hline \multirow[t]{4}{*}{1.} & Kshvathu & - None & 0 & 2 & 0 \\
\hline & (Sneezing) & - 1-5times/day & 1 & & \\
\hline & & - 6-10times/day & 2 & & \\
\hline & & - $>10$ times/day & 3 & & \\
\hline \multirow[t]{4}{*}{2.} & Nasasrava & - None & 0 & 2 & 0 \\
\hline & (Watery nasal & - In one nostril & 1 & & \\
\hline & Discharge) & - In both nostril & 2 & & \\
\hline & & - Out flowing & 3 & & \\
\hline \multirow[t]{4}{*}{3.} & Nasavarodha & - None & 0 & 2 & 0 \\
\hline & (Stiffness) & - $\quad$ Mild without mouth breathing & 1 & & \\
\hline & & - Moderate with occasional mouth breathing & 2 & & \\
\hline & & - Severe with frequent mouth breathing & 3 & & \\
\hline \multirow[t]{4}{*}{4.} & Jwara & - None & 0 & 1 & 0 \\
\hline & (Fever) & - $\quad$ Mild & 1 & & \\
\hline & & - Moderate & 2 & & \\
\hline & & - $\quad$ Severe & 3 & & \\
\hline \multirow[t]{5}{*}{5.} & Kasa & - No Kasa & 0 & 3 & 1 \\
\hline & (Cough) & - Kasa sometimes, does not troublesome & 1 & & \\
\hline & & - Troublesome Kasa but does not disturbing the sleep & 2 & & \\
\hline & & - Very troublesome Kasa, does not even allowing to & 3 & & \\
\hline & & sleep at night & & & \\
\hline \multirow[t]{4}{*}{6.} & Parshvashula & - No Parshvashula & 0 & 2 & 1 \\
\hline & (chest tightness) & - Very often Parshvashula even without attack & 1 & & \\
\hline & & - Parshvashula along with the attack & 2 & & \\
\hline & & - Always Parshvashula & 3 & & \\
\hline \multirow[t]{4}{*}{7.} & Gandha Agyanta & - None & 0 & 2 & 0 \\
\hline & (Anosmia) & - $\quad$ Mild & 1 & & \\
\hline & & - Moderate & 2 & & \\
\hline & & - $\quad$ Severe & 3 & & \\
\hline \multirow[t]{4}{*}{8.} & Mukha & - None & 0 & 1 & 0 \\
\hline & Daurgandhya & - $\quad$ Mild & 1 & & \\
\hline & (Halitosis) & - Moderate & 2 & & \\
\hline & & - Severe & 3 & & \\
\hline
\end{tabular}


Table 3

Result: Result has obtained by Wilcoxon matched pairs signed ranks test.

\begin{tabular}{|l|l|l|l|l|l|l|l|l|l|l|}
\hline Subjective parameters & W/ T+ & T- & Mean & MD & \%Relief & SD & SE & P-value & Significance \\
\cline { 3 - 12 } & & & BT & AT & & & & & & \\
\cline { 2 - 11 } & 36 & 0 & 1.875 & 0.2500 & 1.625 & $86.66 \%$ & 0.5175 & 0.1830 & 0.0078 & Very significant \\
\hline
\end{tabular}

\section{Interpretation}

Result revealed that before treatment mean score was 1.875 with $\mathrm{SD} \pm 0.6409$ which was brought down to 0.2500 with $\mathrm{SD} \pm 0.4629$ after treatment, which showed significant result given at $95 \% \mathrm{CI}$ and P-value 0.0078 . There was $86.66 \%$ relief in patient.

\section{DISCUSSION}

Acharya Sushruta has mentioned that each Pratishyaya should be treated with Vamana Karma except in its acute stage (Su.Ut.24/18). Dushta Pratishyaya is a chronic stage $^{\mathbf{8}}$ of Pratishyaya, therefore there is a great role of Vamana Karma (emesis therapy). Vamana Karma, the first therapy among the Panchakarma and considered as the best line of treatment for the Kaphaja disorders (Ch.Su.25/40). ${ }^{9}$ At first the body should be prepared with Pachana and Deepana Karma (for Amapachana), Snehana and Swedana Karma (for excitation of Doshas), thereafter Vamana Karma has been performed (A.H.Su.13/29). ${ }^{\mathbf{1 0}}$ When Vamaka medicines administered orally then get absorbed by its Ushna, Tikshna, Sukshma, Vyavayi and Vikasi properties and reach to heart due to their Virya (potency). Due to Sukshma and Vyavayi properties, they enter in Stula (macro) and Sukshma (micro) Srotasa (channels) throughout the body. At first, they liquify (Vishyandayanti) the Dosha Sanghata by Ushna and Tikshna properties with Chhedana and Bhedhana. These liquefied and fragmented molecules (Doshas) are articulately to Amashaya (stomach), flowing through "Anu Srotasa" (Anu Pravana Bhava) without adhering to them. Due to Agni and Vayu Mahabhautika constitution and Prabhava, Udana Vayu stimulated and march in upward direction to expel the vitiated Dosha, brought along with them (Ch.Ka.1/5). ${ }^{11}$ Due to elimination of Doshas from the body after Samshodhana (Vamana) Karma, Agni (digestive power) becomes weak. So to restore the strength of Agni and Prana, Peyadi Samsarjana Karma should be followed. ${ }^{\mathbf{1 2}}$ After Vamana Karma symptoms like Kshvathu (sneezing), Sarvendriya Santapa, Jwara (fever), Kasa (coughing), Mukhadaurgandhya (halitosis), Nasasrava (nasal discharge), and Nsavarodha (obstruction) are reduced. Nardiya Laxmivilasa Rasa was started after completion of Samsarjana Karma for Brinhana (nourishment of body) purpose. It has Abhraka, Vidarikanda, Shatavari, Nagabala, Atibala and Gokshur ingredients which are Tridoshahara in properties. They are Madhura in Rasa, Sheeta Virya, Madhura Vipaki and Vatapittashamaka in properties. They are antioxidant and immunomodulators. Karpoora, Jatiphala, Jatikosha, Bhanga, Nichula and Nagvalli are Katu-Tikta in Rasa, Ushna Virya, Katu Vipaki and Vatakaphashamak, they are narcotic and sedative in properties. Vriddhadaru is Madhura Vipaki and Rasayana in nature. Nardiya Laxmivilasa Rasa nourishes all Dhatus of body and has tonic, aphrodisiac, rejuvenate, antipyretic, expectorant, antibacterial and stomachic activities.

\section{Important observations after Vamana Karma:}

Addition of reduction in symptoms of Dushta Pratishyaya (allergic rhinitis), was observed with significant reduction in B.P. as well, before Vamana Karma B.P. was $140 / 96 \mathrm{mmHg}$ which was brought down to $120 / 80 \mathrm{mmHg}$ and also episodes of urticaria rashes reduced moderately.

\section{CONCLUSION}

The present case study shows that Vamana Karma and Nardiya Laxmivalasa Rasa work effectively in the management of Dushta Pratishyaya (Allergic Rhinitis). Vamana Karma followed by oral medication of Nardiya Laxmivalasa Rasa can be efficiently done as no adverse effects were observed. There is $86.66 \%$ 
relief in symptoms of Dushta Pratishyaya. Vamana Karma is the Pradhana Karma for Kapha, it is also significant for Pitta therefore B.P. and episodes of urticaria rashes have also reduced. While there is scope for further research, but it is important that proper diagnosis and Ayurvedic management must be given to attain appreciable results in the management of Dushta Pratishyaya (Allergic Rhinitis).

\section{REFERENCES}

1. Jain A K, Textbook of Physiology, $6^{\text {th }}$ edition Vol-1, 2016, Ch. 107, Page no. 1055 and 1056.

2. Varshney J, Varshney. Allergic Rhinitis: an overview. Indian J otolayngo/Head Neck Surg. 2015; 67(2):1439.

3. H Ralston Stuart, D Penman Ian, et. al., Davidson's Principles and Practice of Medicine, 23rd edition 2018, Ch.17, Page no.622.

4. Dhingra PL, Dhingra Shruti, Diseases of Ear, Nose and Throat \&Head and Neck Surgery, $6^{\text {th }}$ edition, 2014, Ch.30, Page no. 167.

5. Shastri Ambikadutta, Sushruta Samhita, AyurvedaTattva- Sandipika Hindi Commentry, Part-2, Chaukhambha Sanskrit Sansthan Varanasi Reprint, 2016; Uttartantra24, verse 15, Page no. 155.

6. Shastri Ambikadutta, Sushruta Samhita, AyurvedaTattva- Sandipika Hindi Commentry, Part-2, Chaukhambha Sanskrit Sansthan Varanasi Reprint, 2016; Uttartantra 24, verse 18, Page no. 155.

7. Shastri Kaviraj Ambikadatta, Bhaisajyaratnavali, Vidhyotini Hindi Commentry, Chaukhamba Sanskrit Sansthan, Varanasi $1^{\text {st }}$ edition, Vol-1, 2006, Jwara Chikitsa, verse 1223-1236, Page no.94.

8. Shastri Ambikadutta, Sushruta Samhita, AyurvedaTattva- Sandipika Hindi Commentry, Part-2, Chaukhambha Sanskrit Sansthan Varanasi Reprint, 2016; Uttartantra 24, verse 16, Page no. 155.

9. Shastri Kashinath \& Chaturvedi Gourakha Nath, edited Charak Samhita of Agnivesh, revised by Charak and Dridhbala, Part-1, Chaukhambha Sanskrit Sansthan, Varanasi Reprint 2017; Sutrasthana 25, verse 40, Page no. 469.

10. Gupta Atrideva, edited by Upadhyaya Yadunandana, Ashtangahridayam of Vagbhatta, Chaukhambha Prakashan, Varanasi Reprint 2010; Sutrasthana 13, verse 29, Page no. 235.

11. Shastri Kashinath \& Chaturvedi Gourakha Nath, edited Charak Samhita of Agnivesh, revised by Charak and
Dridhbala, Part-2, Chaukhambha Sanskrit Sansthan, Varanasi Reprint 2017; Kalpasthana 1, verse 5, Page no.891.

12. Shastri Kashinath \& Chaturvedi Gourakha Nath, edited Charak Samhita of Agnivesh, revised by Charak and Dridhbala, Part-2, Chaukhambha Sanskrit Sansthan, Varanasi Reprint 2017, Varanasi Reprint 2017; Siddhisthana 1, verse 11-12, Page no. 961-962.

\section{ABBREVIATIONS}

A.H.Su.: AshtangHridyaSutrasthana,

A.H.Ut.: AshtangHridyaUttarasthana,

Ch. Chi: CharakChikitsasthana,

Ch. Ka.: CharakKalpasthana,

Ch. Su.: CharakSutrasthana,

Ma. Ni.: Madhava Nidana

Su. Ut.: SushrutaUttartantra,

Sh. Sa.: Sharangdhar Samhita,

BT: Before Treatment,

AT: After Treatment,

MD: Mean Difference,

SD: Standard Deviation,

SE: Standard Error,

CI: Confidence Interval

\section{Source of Support: Nil \\ Conflict of Interest: None Declared}

How to cite this URL: Mishra Meenu et al: To Study The Effect Of Vamana Karma And Nardiya Laxmivilasa Rasa In The Management Of Dushta Pratishyaya (Allergic Rhinitis): A Case Study. International Ayurvedic Medical Journal \{online\} 2020 \{cited October, 2020\} Available from: http:/www.iamj.in/posts/images/upload/4920 4926.pdf 